\title{
Crohn's Disease: From an Anesthetist's Perspective
}

\author{
Beyazit Zencirci \\ Special DEVAKENT Hospital - Department of Anesthesiology E Reanimation \\ Turkey
}

\section{Introduction}

Human biological diversity involves interindividual variability in morphology, behavior, physiology, development, susceptibility to disease and response to stressful stimuli and drug therapy (phenotypes). Although the human DNA sequence is $99.9 \%$ identical among individuals, the variations may greatly affect a person's disease susceptibility. Many common diseases, and many individual responses to injury, drugs, and non-pharmacologic therapies are genetically complex, characteristically involving an interplay of many genetic variations in molecular and biochemical pathways (1).

The year 2007 marked the publication of adequately powered and successfully replicated genome-wide association studies that identified significant genetic contributors to the risk of common polygenic disease (e.g., coronary artery disease, MI, types I and II diabetes, atrial fibrillation, obesity, asthma, common cancers, rheumatoid arthritis, Crohn's disease and others) (1). Crohn's disease affects a younger age group, with a peak incidence between 10 and 40 years of age. The reported incidence of disease is reported to be 5 to 10 per 100,000/yr (2). Despite advances in medical treatment, many patients still require surgery. The mainstay of management is medical treatment, usually aminosalicylates and steroids. Other immunemodifying agents are used in severe disease. This chapter is going to focus on the relationship between Crohn's disease (disease and used drugs) and anesthetic medicine.

\section{What is Crohn's disease?}

Crohn's disease causes a chronic, nonspecific, transmural inflammation of the intestine that found throughout the GI tract, from the oropharynx to the anus. Crohn's disease also manifests itself in many extraintestinal symptoms of eyes, skin, and joints. The severity and relapsing nature of these symptoms severely affect a patient's quality of life and require dependence on long-term medical therapy (3).

Crohn's disease is incurable, and the natural course of the disease is different for each patient. Patients will have episodes of disease exacerbation followed by periods of relative or complete remission. In a minority of patients, the disease is unrelenting, depending on the location and severity of the disease. The primary treatment of Crohn's disease is medical. Although the time course may vary, at least $75 \%$ of patients will require surgery after 20 years with the disease. Surgery is indicated for those who do not respond adequately to medical therapy and develop complications during the disease process (3). 


\section{Interaction beetween anti-Crohn's drugs and anesthetic drugs}

\subsection{Aminosalicylates}

Sulfasalazine and mesalamine are the two aminosalicylates used for Crohn's disease. The primary antiinflammatory, antipyretic, and analgesic actions of salicylates such as aspirin are due to blockade of prostaglandin synthesis by inhibition of the cyclooxygenase 1 and 2 enzymes. These are effective in maintaining remission in patients with mild-to-moderate diseases (4). Studies demonstrate that both mesalamine and sulfasalazine are efficacious at inducing and maintaining remission, and are often used as long-term maintenance treatments. The improved side effect profile of mesalamine has enabled the use of doses that are much higher in amount than doses possible with sulfasalazine. However, a number of cases of 5-ASA-induced nephrotoxicity have been reported in patients with inflammatory bowel disease $(I B D)(5,6)$. Several case reports have reported renal impairment in the forms of dose-dependent 'analgesic nephropathy', inhibition of cyclooxygenases or hypersensitivity leading to reversible interstitial nephritis in humans. The incidence of renal impairment in patients with IBD treated with 5-ASA is estimated to be one in 100 patients, and interstitial nephritis occurs in one in 500 patients $(7,8)$.

Mahmud et al, were unable to show nephrotoxicity after six months of mesalamine treatment in patients with ulcerative colitis using a low dose of $1.2 \mathrm{~g} /$ day (9). Similarly, Van Staa et al, were not able to demonstrate a relationship between the dose or type of 5-ASA and the incidence of renal disease among 19,025 IBD patients on 5-ASA (10). Based on their findings, interstitial nephritis related to 5-ASA use appears to be a rare event. Although interstitial nephritis occurs infrequently, renal function can be compromised over time with the use of 5-ASA. According to a recent report, de Jong et al, did not find a significant change in creatinine clearance $(\mathrm{CrCl})$ over an 11-year interval in 200 patients with Crohn's disease (11). However, the mean duration of treatment with 5-ASA was 8.6 years, much shorter than the interval that $\mathrm{CrCl}$ was measured. This may reflect why the decline in $\mathrm{CrCl}$ was reported to be within the expected physiological decline in renal function associated with aging. Fortunately, the kidneys have the capacity to regain function after an insult; thus, creatinine measurements need to be taken at the onset and end of treatment rather than time points outside of the actual treatment interval. Also, no case of interstitial nephritis was reported by same author (11). In brief, the time of development of renal impairment is variable and may be seen as late as after several years. There is also a risk of developing irreversible renal disease if not recognized early, in which discontinuation of 5ASA could result in recovery of renal function. Monitoring serum creatinine provides an easy and inexpensive way to prevent a detrimental side effect.

\subsection{Corticosteroids}

For patients with exacerbations leading to moderate or severe Crohn's disease, steroids are the primary therapy. However, they do not help maintain remission and are detrimental when used for long-term treatment. The synthetic analogs of cortisol have been developed with the primary goal of maximizing glucocorticoid activity while minimizing mineralocorticoid effects and decreasing the adverse effects of high quantities of systemically active glucocorticoid. Effects of glucocorticoids that are well documented include inhibition of the production of proinflammatory cytokines such as tumor necrosis factor alpha (TNF-a) and interleukin-1 (IL-l) and chemokines such as IL-8; repression of the transcription of the genes for certain enzymes such as inducible nitric oxide synthase, 
phospholipase A2, and cyclooxygenase 2; and blockade of adhesion molecule expression. These molecular actions of glucocorticoids result in a blockade of leukocyte migration and function and inhibit the effects of numerous important peptide and lipid-derived mediators of inflammation (3).

Corticosteroids can induce clinical remission in Crohn's disease $(60 \%$ success rate compared to $30 \%$ placebo response). The side effects of corticosteroids are extensive and include osteonecrosis, osteoporosis, cataracts, glaucoma, hyperglycemia, hyperlipidemia, hypertension, psychosis, and skin changes (3).

Corticosteroids and its side effects are important in anesthetic practice. Primarily, anesthetist must be aware of the need for corticosteroid replacement not only in patients who have primary adrenal insufficiency but also in patients who have adrenal insufficiency resulting from long-term corticosteroid therapy. Without adequate knowledge, the anesthetist may fail to prepare the patient to withstand the stress of surgery and may open the way for lifethreatening hemodynamic abnormalities that accompany inadequate amounts of corticosteroids (12).

Secondly, its known that a long-term medication with prednisolone resulted in a shorter duration of an atracurium-induced neuromuscular block in patients with ulcerative colitis or Crohn's disease. The underlying chronic IBD itself did not influence the time course of the neuromuscular block. Although the mechanism is not fully understood, several possible sites of interaction of steroids with neuromuscular transmission have been suggested: (i) glucocorticoids have been shown to possess a direct facilitatory effect on the impulse generating end of the motor nerve axon; (ii) corticosteroids act presynaptically stimulating synthesis, spontaneous release, and stimulated release of acetylcholine; (iii) however, at large concentrations, corticosteroids might possess a post-synaptic depressant effect on neuromuscular transmission (13).

On the other hand, medication with prednisolone was associated with a prolonged onset time and attenuated maximum block of rocuronium (14). These data are in contrast to the results of the study mentioned in the previous paragraph. The reasons for the differences between atracurium and rocuronium might be alterations in drug metabolism mediated by the glucocorticoid (14). Alternatively, the presence of chronic IBD itself might influence the effect of the neuromuscular blocking drug: in an experimental model of systemic inflammation, resistance to atracurium was attributed to increased drug binding to a1-acid glycoprotein. Changes in acetylcholine receptor expression in systemic inflammation could was not be observed (15).

A reliable effect of neuromuscular blocking drugs is important to all anaesthesiologists in their clinical routine. A delayed recovery from a neuromuscular block might contribute to severe complications; even increased mortality could be proved previously (16). However, an unexpectedly decreased effect of the drug might also lead to intraoperative complications as a result of coughing or sudden movements. Additionally, it might increase laryngeal morbidity, i.e. injuries of the vocal cords (17).

Thirdly; adolescent or child patients, receiving chronic steroid therapy for IBD underwent major intestinal surgery, can develop vasodilation during anesthesia (especially induction of anesthesia). Systemic hypotension can occur in patients and we can treate them by large volumes of intravenous crystalloid solution which cause intraoperative and postoperative water retention with resultant hypertension as well as occasional pulmonary edema and seizures. Intravenous fluid administration in excess of maintenance requirements and 
calculated fluid losses should be given with caution to children/adolescent receiving highdose steroids who undergo major intestinal surgery. Perioperative fluid retention under those circumstances may be treated best with early diuretic administration (18).

\subsection{Antibiotics}

Although antibiotics are not used to treat specific bacterial organisms, they have been found to be effective in the treatment of Crohn's disease, especially for the perianal area. Metronidazole is the most common agent employed, although ciprofloxacin has also been used. By decreasing the amount of bacterial flora in the intestinal lumen, they act to prevent the infectious complications of Crohn's disease, such as abscesses and fistulas (3). Clinical trials have shown their efficacy in inducing remission $(19,20)$.

Although rare, prolonged and high-dose administration of metronidazole may induce cerebellar lesions. Increased awareness of this phenomenon is important, as these lesions are reversible with discontinuation of this drug (21). Therefore, metronidazole dosages should be reduced in patients with liver dysfunction to prevent the accumulation of metronidazole, which can lead to CNS dysfunction and peripheral neuropathy (22).

Knorr et al reported a case of Q-T interval prolongation in a pediatric patient with no known risk factors (including hypokalemia, hypomagnesemia, hypocalcemia, bradycardia, starvation etc.) for the development of a long Q-T syndrome (LQTS) (23). After 48 hours of ciprofloxacin administration, the patient became bradycardic. Antimicrobial therapy was changed to ampicillin and ciprofloxacin was discontinued. The patient's bradycardia persisted for three days after the initial detection, and his Q-T prolongation was deemed resolved six days after detection; no other cardiac abnormalities have been reported after this day. The patient's Q$\mathrm{T}$ interval was normalized within seven days of ciprofloxacin discontinuation. The patient did not have any further cardiac anomalies.

The pharmacologic mechanism of drug-induced LQTS is proposed to be via the blockade of delayed rectifier potassium channels of the ventricular myocardium during the repolarization phase. This blockade prolongs the cardiac action potential and allows early afterdepolarization (EAD), which results in the development of a second action potential. The second action potential may create a premature ventricular complex on an ECG, and if this dysrhythmia becomes self-sustaining, the resulting pattern of EADs reveals itself as a "twisting of the points" on the ECG. With the development of dysrhythmia, the patient may be asymptomatic or may present with syncope, palpitations, ventricular tachycardia, or sudden death $(24,25)$. Fluoroquinolone-induced Q-T prolongation is most commonly associated with gatifloxacin, moxifloxacin, and the withdrawn agents sparifloxacin and grepafloxacin (26). This case demonstrated that the use of ciprofloxacin in patients (esp. pediatric) should be restricted to situations in which there is no other safe and effective alternative to treat the infection. It is important for clinicians to familiarize themselves with the drugs that may propagate Q-T prolongation as well as the risk factors that increase the probability of developing drug-induced LQTS (23).

\subsection{Immunosuppressive drugs}

As the increasing number of of evidence points to an immunological etiology of IBD, efforts have been made to utilize various immunotherapies. The drugs most commonly used are azathioprine and its metabolite, 6-mercaptopurine (6-MP), and antimetabolites that inhibit DNA synthesis (27). After administration of azathioprine or 6-MP, the 6-thioguanine 
nucleotides accumulate intracellularly and are believed to mediate the biological actions of these drugs (3).

Despite over 50 years of investigation, the precise molecular basis for the therapeutic effects of the purine analogs is not known. However, intracellular accumulation of 6-thioguanine nucleotides causes inhibition of the pathways of purine nucleotide metabolism and DNA synthesis and repair, resulting in inhibition of cell division and proliferation. It is plausible, but not proven, that antiproliferative or functionally inhibitory actions on cells of the immune system, such as lymphocytes, underlie the immunosuppressive actions of azathioprine and 6-MP (3). Their value was established in a study that showed $67 \%$ of patients with a clinical response compared to $8 \%$ in the placebo group, although the effect was delayed by 3 to 6 months. In addition, $75 \%$ of patients were able to discontinue or reduce their steroid doses (27). A metaanalysis of nine trials revealed that azathioprine and 6-MP are effective in patients with an active disease, while the adverse side effects approached $10 \%$ (28).

Two categories of adverse effects to azathioprine and 6-MP have been described: allergic, occurring early during treatment; and dose-related, generally occurring later. Allergy to these drugs can manifest as pancreatitis, fever, rash, nausea, diarrhea, and an allergic hepatitis. Approximately $50 \%$ of the IBD population beginning treatment with azathioprine or 6-MP will experience an allergic reaction to the drug, which can be confirmed by rechallenge if necessary. Dose-related toxicities of azathioprine or 6-MP include bone marrow depression leading to leukopenia ( $10 \%$ cumulative risk), anemia, thrombocytopenia, and hepatic toxicity. If severe, leukopenia can potentially cause profound immune suppression and thus predispose to opportunistic infections or neoplasms. If leukopenia and a serious infection develop in a patient receiving azathioprine or 6-MP, reversal of bone marrow suppression is usually possible with granulocyte colony-stimulating factor. Decreases in the white blood cell $(W B C)$ or elevations in liver function tests (LFTs) are common and generally respond to small dose reductions if needed, without discontinuation. The most important criteria for the success of azathioprine and 6-MP include adequate dosing and duration of treatment and individual metabolism of these drugs based on detectable thiopurine methyltransferase activity (29). Withdrawal of drug has shown a $70 \%$ relapse rate (28).

Methotrexate is a folate analog that inhibits purine and pyrimidine synthesis and has been shown in a number of trials to be effective in treating Crohn's disease (30). The principal biochemical action of methotrexate, and the mechanism that is believed to be responsible for the drug's cytotoxic activity, is inhibition of dihydrofolate reductase. It has alternatively been proposed that the antiinflammatory action of methotrexate may be mediated by inhibition of cytokine release or by increased release of the endogenous antiinflammatory autocoid adenosine. Methotrexate may also have effects on activated T lymphocytes, a critical part of the inflammatory infiltrate in IBD. However, this drug has significant side effects, including hepatotoxicity. and bone marrow suppression, and thus is reserved for patients wIth severe Crohn's that is refractory to other therapies (3).

The latest class of drugs that has resulted in huge advancements in the treatment of Crohn's disease are the anti-tumour necrosis factor alpha (TNF- $\alpha$ ) agents. Levels of TNF- $\alpha$ are increased in Crohn's disease, and in a study of its efficacy, it was noted to produce fistula healing (3). Infliximab, a monoclonal antibody against TNF- $\alpha$, is licensed for the management of severe active Crohn's disease and moderate to severe ulcerative colitis in 
patients whose condition has not responded adequately to treatment with a corticosteroid and a conventional immunosuppressant or who are intolerant of them (31). It has been associated with acute demyelination of the central nervous system (32-34). Recently, Drummonad at al. reported profound postoperative muscle weakness in a patient who had been treated with infliximab (35). However, reports in literature suggesting interactions between infliximab and any anaesthetic drugs are unavailable. It is possible that the immunosuppressive effect of the hydrocortisone bolus (given at the induction of anesthesia) or simply of the surgery itself may have interacted with the infliximab, hastening the onset of symptoms. Therefore every patients recently treated with infliximab should have a neurological examination documented at pre-operative assessment in order to provide a in case should problems occur postoperatively.

On the other hand; it is well known that infliximab can worsen congestive heart failure. The preliminary results of a study assessing the heart function (by means of electro-and echocardiogram) during infliximab therapy, in twelve paediatric IBD patients $(9 \mathrm{Crohn}$ 's disease, 3 ulcerative colitis), have been published (36). Seven out of 12 patients showed cardiac disturbances consisting of dilation of the cardiac cavities $(5$ cases $)$ and septal hypertrophy (2 cases), with a direct correlation between the length of Q-T interval and the systolic and diastolic diameter of the left ventricle. These findings point to an increased risk of developing arrhythmias in these patients. However, further and more complete studies should be done before recommendations about cardiologic work-up required before surgery.

Vitamin B12 (cyanocobalamin) is an integral component of two biochemical reactions in humans: the conversion of L-methylmalonyl coenzyme A into succinyl coenzyme A and the formation of methionine by methylation of homocysteine. The transmethylation reaction is essential to DNA synthesis and to the maintenance of the myelin sheath by the methylation of myelin basic protein. Active vitamin B12 contains cobalt in its reduced form $\left(\mathrm{Co}^{+}\right)$. Nitrous oxide produces irreversible oxidation to the $\mathrm{Co}++$ and $\mathrm{Co}$ forms that renders vitamin B12 inactive. The etiologies of vitamin B12 deficiency include many situations such as malabsorption (because of celiac disease, colitis, etc.). Patients with vitamin B12 deficiency are exceedingly sensitive to neurologic deterioration following nitrous oxide anesthesia. If unrecognized, the neurologic deterioration becomes irreversible and may result in death (37).

\section{Certain circumstances in Crohn's disease which may affect anesthesia}

\subsection{Anemia}

Anemia is the most common systemic complication of IBD (38). Anemia in IBD is a prototype of a combination of iron deficiency and anemia of inflammation (i.e. anemia of chronic disease) which is caused by negative effects of an activated immune system at different levels of erythropoiesis. Inflammation affects three major steps essential for normal erythropoiesis and can, therefore, lead to the development of anemia of inflammation. These effects are: (i) an immunity-driven diversion of iron traffic leading to retention of the metal in macrophages and thus to iron-deficient erythropoiesis; (ii) blunting of the biological activity of erythropoietin, the major erythropoiesis-stimulating hormone; and (iii) inhibition of the differentiation and proliferation of erythroid progenitor cells (39).

Anemia in IBD can also be induced by deficiency of vitamins, such as cobalamin and folic acid, a condition which further impairs the proliferation of hematopoietic progenitor cells 
(40), or by certain medications, such as thiopurine analogs (6-mercaptopurine, azathioprine), sulfasalazine and methotrexate, most of which can inhibit erythropoiesis directly (41).

The severity of anemia in IBD varies considerably (42). The lower hemoglobin levels below which anemia was defined as present were those proposed by the World Health Organization (non-pregnant women, $12.0 \mathrm{~g} / \mathrm{dL}$; men $13.0 \mathrm{~g} / \mathrm{dL}$ ). Most patients with IBD have mild to moderate anemia (hemoglobin above $10.0 \mathrm{~g} / \mathrm{dL}$ ), but in the presence of bleeding episodes, the hemoglobin concentration may decrease further $(41,43)$.

The persistence of anemia is associated with impaired cardiac and renal function, reduced systemic oxygen delivery, decreased physical activity, fatigue, and impaired quality of life or ability to work $(41,43,44)$. However, anemia is a comorbid condition which is associated with other diseases (such as transfusion associated hepatitis $C$ ) or even death (45).

Preoperative anemia is a major risk factor for adverse outcome in major surgery and, it's also one of the most important risk factor for perioperative blood transfusions (46). With various multivariate statistics and propensity score matching in some studies, the authors unanimously found that preoperative anemia and perioperative allogeneic blood transfusions $(A B T)$ were both independent risk factors for postoperative mortality, ischemia, and infections (47).

The question of what hemoglobin/hematocrit $(\mathrm{Hb} / \mathrm{Hct})$ level justifies the risks associated with the administration of blood has been widely discussed. The inviolable "10-30" rule has been abandoned. Experience with several patient subpopulations (renal failure, military casualties, Jehovah's Witnesses) and systematic study has revealed that considerable greater degrees of anemia can be well tolerated and that, in many situations, morbidity and mortality rates did not increase until $\mathrm{Hb}$ levels fell below $7 \mathrm{~g} / \mathrm{dL}(48,49)$. As significant as the identification of a $7 \mathrm{~g} / \mathrm{dL}$ threshold for increased morbidity was the observation that stable general medical-surgical managed to a target $\mathrm{Hb}$ of $10 \mathrm{~g} / \mathrm{dL}$ fared less well than a parallel group managed with a transfusion trigger of $7 \mathrm{~g} / \mathrm{dL}$ (48). That observation implies an adverse effect of transfusion. Accordingly, the contemporary transfusion trigger for stable general medical-surgical patients is $21 \% / 7.0 \mathrm{~g} / \mathrm{dL}(\mathrm{Hct} / \mathrm{Hb})$. However, there is evidence that the threshold for patients with cardiac disease should be higher (48). That evidence includes an investigation supporting a threshold of 30\%/10 g/dL $(\mathrm{Hct} / \mathrm{Hb})$ in patients who have suffered a recent acute myocardial infarction (50), and an observational study suggests better outcomes in patients with several cardiac diagnoses (cardiac and vascular surgery, ischemic heart disease, dysrhythmias) above a threshold of $9.5 \mathrm{~g} / \mathrm{dL}$ (51). The Practice Guidelines for Blood Component Therapy developed by the American Society of Anesthesiologists (ASA) state that "red blood cell transfusion is rarely indicated when the hemoglobin concentration is greater than $10 \mathrm{~g} / \mathrm{dL}$ and is almost always indicated when it is less than $6 \mathrm{~g} / \mathrm{dL}$. The indications for autologous transfusion may be more liberal than for allogeneic (homologous) transfusion" (52).

Blood transfusions are widely used as an immediate intervention for rapid correction of severe or life-threatening anemia. However, such transfusions do not correct the underlying pathology and do not have a lasting effect. The decision on whether to administer blood should not, therefore, be based only on the hemoglobin level, but should also take clinical symptoms and co-morbidity into account. Whether blood transfusions affect immune function and whether they are cause-effectively linked to mortality in patients undergoing surgery (46) or being treated in intensive care units remains controversial (53). 
The clinician's responsibility is to anticipate, on a patient-by-patient basis, the minimum $\mathrm{Hb}$ level (probably in the range of 7 to $10 \mathrm{~g} / \mathrm{dL}$ ) that will avoid organ damage due to oxygen deprivation. Determining this individual "transfusion trigger" requires reference to the many elements of patient condition that determine demand for the delivery of oxygen and the physiologic reserve (54), including ongoing blood loss and the potential for sudden blood loss. Ultimately, the decision to transfuse red blood cells $(R B C s)$ should be made on the basis of the clinical judgment that the oxygen-carrying capacity of the blood must be increased to prevent oxygen consumption from outstripping oxygen delivery. That judgment is based on an understanding of the physiologic mechanisms that compensate for anemia and the limits of those mechanisms.

\subsection{Respiratory problems}

The pathogenesis of IBD-associated respiratory lesions is unknown. The inflammatory lesions seen beneath the bronchial epithelium are similar to those observed beneath the colonic epithelium in IBD. Both epithelia have columnar structures and mucosal glands, and both sites are challenged constantly by foreign antigens. There are two possible hypotheses: (i) a systemic immunologically-mediated phenomenon originating from the intestinal inflammatory process underlies the bronchial/parenchymal changes in the lungs; or (ii) a defect in the regulation of local immune response which is evident in both gastrointestinal and respiratory tract in response to as yet unknown antigens (55).

While clinically apparent bronchopulmonary disease complicating IBD is rare, the function of the small airways and the diffusion capacity of the lungs has been shown to be affected in IBD patients without any clinical respiratory involvement $(56,57)$. Heatley et al. Reported reduced diffusion capacity for carbon monoxide in $25 \%$, and spirometric abnormalities in $50 \%$, of 102 patients with IBD (58). Adenis et al., using clearance of 99mTechnitium isotopic DTPA, suggested that patients with Crohn's disease may have increased pulmonary vascular permeability due to latent alveolitis (57).

Respiratory symptoms can occur at any time in the history of IBD. Most interstitial lung diseases associated with IBD start gradually with weeks or months of breathlessness associated with cough. Bronchiolitis can progress unrecognised as there is no distinctive pattern of physical signs (59). Despite exertional dyspnoea, there may be no audible signs on auscultation. Radiological signs are also variable. Chest radiographs may show diffuse or patchy infiltrates but can be normal. Computed tomography scan is more helpful in demonstrating diffuse nodular or ground glass opacities which maybe patchy or uniform (60). Pulmonary function tests usually show a restrictive defect in interstitial lung involvement with reduced gas transfer and resting/exercise hypoxaemia. Broncho-alveolar lavage, useful in ruling out infectious causes, generally shows lymphocytosis. A lung biopsy is usually necessary to confirm the diagnosis and may aid in indicating prognosis (61)

Drug-induced interstitial lung disease has been well-reported in IBD, with clinical features very similar to IBD-associated interstitial lung diseases. Most cases have been attributed to salicylates and mesalazine therapy (62). Salicylates (sulphasalazine and 5-ASA) can induce different lung diseases such as bronchiolitis obliterans, bronchiolitis obliterans with organising pneumonia $(B O O P)$, and interstitial pneumonitis with the most common being eosinophilic pneumonitis. 
Drug-induced lung disease can be confirmed by drug rechallenge and improvement has occurred following drug withdrawal. Generally, prognosis is favourable in the majority of salicylate-induced interstitial lung diseases, but fatal outcomes due to irreversible lung fibrosis and rapidly progressive interstitial lung disease have been described (63). Hypersensitivity pneumonitis may occur with methotrexate. This is a serious complication, occasionally fatal, with a reported prevalence of 3.1 to $11.6 \%$ in patients receiving long-term low-dose therapy $(64,65)$. The clinical features include dyspnoea, fever and cough with diffuse alveolar and interstitial shadowing on chest X-ray. Treatment requires the immediate withdrawal of methotrexate and high dose corticosteroids. A few cases of azathioprine-induced interstitial lung diseases have been reported in non-IBD patients. Opportunistic infections have been described in patients treated with immunosuppressants, particularly cyclosporin, and most recently, infliximab $(66,67)$.

Most respiratory disease associated with IBD responds well to corticosteroids with the exception of constrictive bronchiolitis obliterans (68). But, in some patients, pathological changes such as bronchiectasis and bronchiolitis obliterans are irreversible. Initial treatment of airways inflammation is with inhaled corticosteroids. Systemic corticosteroids are used to treat parenchymal disease (BOOP, interstitial pneumonitis and necrotic nodules). Methotrexate or salicylates should be withdrawn as potential causes of interstitial lung disease. The duration and dosage of corticosteroid treatment should be guided by symptomatic response and pulmonary function tests. In the case of BOOP, the duration of corticosteroid treatment is usually six months and clinical improvement can be seen within days to weeks (69).

\subsection{Renal problems}

Secondary amyloidosis $(S A)$ is a rare but serious complication of IBD, generally seen in Crohn's disease. Indeed SA is frequently described as a major cause of death in patients with Crohn's disease (70). At least $1 \%$ of patients with Crohn's disease develop SA. In literature, the time lapse between the onset of Crohn's disease and the diagnosis of SA has been reported to range from one to 21 years. In most patients, protein-uria heralded the onset of renal involvement from amyloid and occurred from three to 15 years after Crohn's disease diagnosis (71). Renal failure is the most common clinical presentation of SA, ranging from nephrotic syndrome and impaired renal function-to renal failure, with a potential for high morbidity (72).

So far no effective treatment for SA has been identified. Multiple therapeutic strategies have been employed with discouraging results, including colchicine and immunosuppressive drugs such as tumor necrosis factor alpha inhibitors The therapeutic approach to these patients should be dual. On the one hand it aims at minimizing the activity of the underlying disease in order to mitigate or prevent serum amyloid A (SAA) production, the precursor of plasma amyloid that is deposited in tissues and will be responsible for their malfunction. On the other hand it is aimed at treating the disease once it is established. The treatment of SA has two pillars: a) improvement of renal dysfunction; and b) reduction of inflammation, the constant source of SAA, thus trying to prevent the formation of amyloid, and hence curb the progression of disease $(73,74)$. Dialysis and renal transplantation are reserved for patients with end-stage renal failure. Survival rates for these patients have improved in recent years with the introduction of these drugs, but there is still no standardized treatment, and prognosis remains dismal (75). 


\subsection{Pain problems}

Pain is a common component of IBD, especially during acute inflammatory episodes. The substances involved in visceral hyperalgesia are present throughout the gastrointestinal tract and their synthesis is increased during acute clinical episodes of IBD (76-79). On the other hand, opioid-binding proteins are involved as acutephase reactants and their concentrations are elevated in IBD (80), and the modulation of pain during this disease is therefore unclear.

However, medical management of IBD remains challenging and cannot always control all aspects of the disease. Even with therapy, patients frequently suffer not only from diarrhea and rectal bleeding but also from abdominal pain, cramps and arthralgia. Although the established disease activity indices only include abdominal pain as one variable, pain occurs throughout the body with pain attacks severely diminishing the patient's health-related quality of life $(H R Q O L)$ and interfering with their social and occupational habits. Localization of pain is a matter of great interest because of the different treatment options for abdominal pain and arthralgia. While the treatment of arthralgia could be composed of physical therapy, steroids or sulfasalazine, abdominal pain requires a more effective antiinflammatory therapy. In cases of persistent pain despite remission, IBS-like symptoms, depression or drug-related side effects must also be considered (81).

The use of analgesics and their dosage is difficult to gauge and should be well evaluated. Pain killers have a variety of known effects and side effects. Given the gastrointestinal side effects and the possibility of aggravating mucosal inflammation, non-steroidal antiinflammatory drugs (NSAID) should be avoided in IBD. However, opioids might also worsen pain in IBD patients because long-term use of opioids may also be associated with the development of abnormal sensitivity to pain and a progressive decline in plasma cortisol levels (82). Consequently, Smith and coworkers recently showed that treatment with lowdose naltrexone improved disease course and HRQOL of Crohn's disease (83). An alternative explanation for the discrepancy between use of analgesics and perception of pain might be the high prevalence of functional somatic symptoms (IBS-like symptoms) among IBD patients (84).

Previous studies have demonstrated an increase in opioid requirements and a large variability in patients with Crohn's disease or ulcerative colitis compared with controls undergoing abdominal major surgery. Two recent studies have indicated the existence of diffuse hyperalgesia during an intestinal inflammatory process $(85,86)$. Verne and colleagues confirmed that patients with functional bowel disorder have visceral cutaneous hyperalgesia that are distributed over a considerable rostro-caudal distance but are yet optimally expressed in lumbosacral dermatoma (87). Also, that study demonstrate that the inflammatory status seems to influence opioid requirements during surgery for IBD. Inflammation induces visceral and cutaneous hyperalgesia that may explain the decrease in opioid requirements in patients with quiescent IBD compared with those who have an active IBD. On the other hand, during surgery, pain stimulation was much more related to painful stimuli to the abdominal wall than to direct stimuli to the inflammatory bowel. Hence, we may speculate that increased opioid requirements during abdominal wall stimulation are linked to this somatic hyperalgesia in lumbosacral referred dermatoma. However, the decrease in opioid consumption may also be related to changes in pharmacokinetic factors due to the inflammation (88). 


\section{Conclusion}

We are faced with the Crohn's disease in practice of anesthesia. We usually pay attention to the type of surgery. However, our patients's clinical status (nutrition, blood protein level, etc.), interactions between anesthetic drugs and patient used drugs are impotant too. Thus we can help prevent complications, early discern to negative signals and start effective treatments. Nothing is simple, nothing is resolved.

\section{References}

[1] Podgoreanu MV \& Mathew JP (2009). Genomic Basis of Perioperative Medicine. In: Clinical Anesthesia. Barash PG, Cullen BF, Stoelting RK, Cahalan MK \& Stock MC (Eds), 115-36. Lippincott Williams \& Wilkins, ISBN 978-078-1787-63-5, Philadelphia.

[2] Carter MJ, Lobo AJ, Travis SP \& IBD Section of the British Society of Gastroenterology (2004). Guidelines for the management of inflammatory bowel disease in adults. Gut. Vol.53, No.suppl V, (September 2004), pp. v1-v16, ISSN 0017-5749

[3] Welton ML, Shelton AA, Chang GJ \& Varma MG (2008). Colon, Rectum, and Anus. In: Surgery Basic Science and Clinical Evidence 2nd ed. Norton JA, Barie PS, Bollinger RR, Chang AE, Lowry SF, Mulvihill SJ, Pass HI \& Thompson RW (Eds), 1011-1110. Springer, ISBN 978-038-7308-00-5, New York.

[4] Malchow H, Ewe K, Brandes JW, Goebell H, Ehms H, Sommer H \& Jesdinsky H (1984). European Cooperative Crohn's Disease Study (ECCDS): results of drug treatment. Gastroenterology. Vol.86, No.2 (February 1984), pp. 249-66, ISSN 0016-5085

[5] Corrigan G \& Stevens PE (2000). Review article: interstitial nephritis associated with the use of mesalazine in inflammatory bowel disease. Alimentary Pharmacology $\mathcal{E}$ Therapeutics. Vol.14, No.1 (January 2000), pp. 1-6, 1SSN 1365-2036

[6] Loftus EV Jr, Kane SV \& Bjorkman D. Systematic review: short-term adverse effects of 5aminosalicylic acid agents in the treatment of ulcerative colitis. Alimentary Pharmacology \& Therapeutics. Vol.19, No.2, (January,2004), pp. 179-89. 1SSN 13652036

[7] World MJ, Stevens PE, Ashton MA \& Rainford DJ (1996). Mesalazine-associated interstitial nephritis. Nephrology Dialysis Transplantation. Vol.11, No.4, (April 1996), pp. 614-21, ISSN 1460-2385

[8] Thuluvath PJ, Ninkovic M, Calam J \& Anderson M (1994). Mesalazine induced interstitial nephritis. Gut. Vol.35, No.10, (October 1994), pp. 1493-6, ISSN 0017-5749

[9] Mahmud N, O’Toole D, O'Hare N, Freyne PJ, Weir DG \& Kelleher D (2002). Evaluation of renal function following treatment with 5-aminosalicylic acid derivatives in patients with ulcerative colitis. Alimentary Pharmacology \& Therapeutics. Vol.16, No.2, (February 2002), pp. 207-15, 1SSN 1365-2036

[10] Van Staa TP, Travis S, Leufkens HG \& Logan RF (2004). 5-aminosalicylic acids and the risk of renal disease: A large British epidemiologic study. Gastroenterology. Vol.126, No.7, (July 2004), pp. 1733-9, ISSN 0016-5085 
[11] de Jong DJ, Tielen J, Habraken CM, Wetzels JF \& Naber AH (2005). 5-Aminosalicylates and effects on renal function in patients with Crohn's disease. Inflammatory Bowel Disease. Vol.11, No.11, (November 2005), pp. 972-6, ISSN 1536-4844

[12] Wakim JH \& Sledge KC (2006). Anesthetic implications for patients receiving exogenous corticosteroids. American Association of Nurse Anesthetists Journal. Vol.74, No.2, (April 2006), pp. 133-9, ISSN 0094-6354

[13] Soltész S, Mencke T, Mey C, Röhrig S, Diefenbach C \& Molter GP (2008). Influence of a continuous prednisolone medication on the time course of neuromuscular block of atracurium in patients with chronic inflammatory bowel disease. British Journal of Anaesthesia.Vol.100, No.6, (June 2008), pp. 798-802, ISSN 0007-0912

[14] Soltész S, Mencke T, Stunz M, Diefenbach C, Ziegeler S \& Molter GP (2009). Attenuation of a rocuronium-induced neuromuscular block in patients receiving prednisolone. Acta Anaesthesiologica Scandinavica. Vol.53, No.4, (April 2009), pp. 443-8, ISSN 0001-5172

[15] Fink H, Luppa P, Mayer B, Rosenbrock H, Metzger J, Martyn JA \& Blobner M (2003). Systemic inflammation leads to resistance to atracurium without increasing membrane expression of acetylcholine receptors. Anesthesiology. Vol.98, No.1, (January 2003), pp. 82-8, ISSN 0003-3022

[16] Arbous MS, Meursing AE, van Kleef JW, de Lange JJ, Spoormans HH, Touw P, Werner FM \& Grobbee DE (2005). Impact of anesthesia management characteristics on severe morbidity and mortality. Anesthesiology. Vol.102, No.2, (February 2005), pp. 257-68, ISSN 0003-3022

[17] Mencke T, Echternach M, Plinkert PK, Johann U, Afan N, Rensing H, NoeldgeSchomburg G, Knoll H \& Larsen R (2006). Does the timing of tracheal intubation based on neuromuscular monitoring decrease laryngeal injury? A randomized prospective, controlled trial. Anesthesia and Analgesia. Vol.102, No.1 (January 2006), pp. 306-12, ISSN 0003-2999

[18] Mulvihill SJ \& Fonkalsrud EW (1984). Complications of excessive operative fluid administration in children receiving steroids for inflammatory bowel disease. Journal of Pediatric Surgery. Vol.19, No.3, (June 1984), pp. 274-7, ISSN 00223468

[19] Sutherland L, Singleton J, Sessions J, Hanauer S, Krawitt E, Rankin G, Summers R, Mekhjian H, Greenberger N, Kelly M, Levine J, Thomson A, Alpert E \& Prokipchuk E (1991). Double blind, placebo controlled trial of metronidazole in Crohn's disease. Gut. Vol.32, No.9 (September 1991), pp. 1071-5, ISSN 0017-5749

[20] Rutgeerts P, Hiele M, Geboes K, Peeters M, Penninckx F, Aerts R \& Kerremans R (1995). Controlled trial of metronidazole treatment for prevention of Crohn's recurrence after ileal resection. Gastroenterology. Vol.108, No.6, (June 1995), pp. 1617-21, ISSN 0016-5085

[21] Ito H, Maruyama M, Ogura N, Fujioka T, Iwasaki Y, Aikawa A \& Hasegawa A (2004). Reversible cerebellar lesions induced by metronidazole therapy for helicobacter pylori. Journal of Neuroimaging. Vol.14, No.4, (October 2004), pp. 369-71, ISSN 15526569 
[22] Horlen CK, Seifert CF \& Malouf CS (2000). Toxic metronidazole-induced MRI changes. Annals of Pharmacotherapy. Vol.34, No.11, (November 2000), pp.1273-5, ISSN 15426270

[23] Knorr JP, Moshfeghi M \& Sokoloski MC (2008). Ciprofloxacin-induced Q-T interval prolongation. American Journal of Health System Pharmacy. Vol.65, No.6, (March 2008), pp. 547-51, ISSN 1079-2082

[24] Roden DM (2004). Drug-induced prolongation of the QT interval. New England Journal of Medicine. Vol.350, No.10, (March 4, 2004), pp. 1013-22, ISSN 0028-4793

[25] Owens RC Jr (2004). QT prolongation with antimicrobial agents: understanding the significance. Drugs. Vol.64, No.10, (2004), pp. 1091-124, ISSN 1179-1950

[26] Makaryus AN, Byrns K, Makaryus MN, Natarajan U, Singer C \& Goldner B (2006).. Effect of ciprofloxacin and levofloxacin on the QT interval: is this a significant "clinical" event? Southern Medical Journal. Vol.99, No.1 (January 2006), pp. 52-6, ISSN 1541-8243

[27] Present DH, Korelitz BI, Wisch N, Glass JL, Sachar DB \& Pasternack BS (1980). Treatment of Crohn's disease with 6-mercaptopurine. A long-term, randomized, double-blind study. New England Journal of Medicine. Vol.302, No.18, (May 1, 1980), pp. 981-7, ISSN 0028-4793

[28] Pearson DC, May GR, Fick GH \& Sutherland LR (1995). Azathioprine and 6mercaptopurine in Crohn's disease. A meta-analysis. Annals of Internal Medicine. Vol.123, No.2, (July 15, 1995), pp.132-42, ISSN 0003-4819

[29] Katz S (2005). Update in medical therapy of ulcerative colitis: newer concepts and therapies. Journal of Clinical Gastroenterology. Vol.39, No.7, (August 2005), pp. 55769, ISSN 0192-0790

[30] Alfadhli AA, McDonald JW \& Feagan BG (2009). Methotrexate for induction of remission in refractory Crohn's disease. In: Cochrane Database of Systematic Reviews. (21 July 2004), Avaliable from:

<http:/ / onlinelibrary.wiley.com/o/cochrane/clsysrev/articles/CD003459/frame. html>

[31] Ngo B, Farrell CP, Barr M, Wolov K, Bailey R, Mullin JM \& Thornton JJ (2010). Tumor necrosis factor blockade for treatment of inflammatory bowel disease: efficacy and safety. Current Molecular Pharmacology. Vol.3, No.3, (November 1, 2010), pp. 145-52, ISSN 1874-4672

[32] Singer OC, Otto B, Steinmetz H \& Ziemann U (2004). Acute neuropathy with multiple conduction blocks after TNFalpha monoclonal antibody therapy. Neurology. Vol.63 No.9, (November 9, 2004), pp. 1754, ISSN 0028-3878.

[33] Richez C, Blanco P, Lagueny A, Schaeverbeke T \& Dehais J. Neuropathy resembling CIDP in patients receiving tumor necrosis factor-alpha blockers. Neurology. Vol.64, No.8, (April 26, 2005), pp. 1468-70, ISSN 0028-3878

[34] Cocito D, Bergamasco B, Tavella A, Poglio F, Paolasso I, Costa P, Ciaramitaro P \& Isoardo $G$ (2005). Multifocal motorneuropathy during treatment with infliximab. Journal of the Peripheral Nervous System. Vol.10, No.4, (December 2005), pp. 386-7, ISSN 1085-9489 
[35] Drummond AD, Williamson RM, Silverdale MA \& Rothwell MP (2008). Postoperative muscle weakness in a patient recently treated with infliximab. Anaesthesia. Vol.63, No.5, (May 2008), pp. 548-50, ISSN 0003-2409

[36] Barbato M, Curione M, Viola F, Versacci P, Parisi F, Amato S \& Cucchiara S (2006). Cardiac involvement in children with IBD during infliximab therapy. Inflammatory Bowel Disease. Vol.12, No.8, (August 2006), pp. 828-9, ISSN 1536-4844

[37] Flippo TS \& Holder WD Jr (1993). Neurologic degeneration associated with nitrous oxide anesthesia in patients with vitamin B12 deficiency. Archives of Surgery. Vol.128, No.12, (December 1993), pp. 1391-5, ISSN 0004-0010

[38] Gasche C, Berstad A, Befrits R, Beglinger C, Dignass A, Erichsen K, Gomollon F, Hjortswang H, Koutroubakis I, Kulnigg S, Oldenburg B, Rampton D, Schroeder O, Stein J, Travis S \& Van Assche G (2007). Guidelines on the diagnosis and management of iron deficiency and anemia in inflammatory bowel diseases. Inflammatory Bowel Disease. Vol.13, No.12, (December 2007), pp.1545-53, ISSN 15364844

[39] Weiss G \& Gasche C (2010). Pathogenesis and treatment of anemia in inflammatory bowel disease. Haematologica. Vol.95, No.2, (February 2010), pp. 175-8, ISSN 03906078

[40] Rodriguez RM, Corwin HL, Gettinger A, Corwin MJ, Gubler D \& Pearl RG (2001). Nutritional deficiencies and blunted erythropoietin response as causes of the anemia of critical illness. Journal of Critical Care. Vol.16, No.1 (March 2001), pp. 3641, ISSN 0883-9441

[41] Gomollon F \& Gisbert JP (2009). Anemia and inflammatory bowel diseases. World Journal of Gastroenterology. Vol.15, No.37, (October 7, 2009), pp. 4659-65, ISSN 10079327

[42] Kulnigg S \& Gasche C (2006). Systematic review: managing anaemia in Crohn's disease. Alimentary Pharmacology \& Therapeutics. Vol.24, No.11-12, (December 2006), pp. 1507-23, ISSN 0953-0673

[43] Gasche C, Lomer MC, Cavill I \& Weiss G (2004). Iron, anaemia, and inflammatory bowel diseases. Gut. Vol.53, No.8, (August 2004), pp. 1190-7, ISSN 0017-5749

[44] Wells CW, Lewis S, Barton JR \& Corbett S (2006). Effects of changes in hemoglobin level on quality of life and cognitive function in inflammatory bowel disease patients. Inflammatory Bowel Disease. Vol.12, No.2, (February 2006), pp. 123-30, ISSN $1536-4844$

[45] Cucino C \& Sonnenberg A (2001). Cause of death in patients with inflammatory bowel disease. Inflammatory Bowel Disease. Vol.7, No.3, (August 2001), pp. 250-5, ISSN 1536- 4844

[46] Beattie WS, Karkouti K, Wijeysundera DN \& Tait G (2009). Risk associated with preoperative anemia in noncardiac surgery: A single-center cohort study. Anesthesiology. Vol.110, No.3, (March 2009), pp. 574-81, ISSN 0003-3022

[47] Spahn DR. Anemia and patient blood management in hip and knee surgery: a systematic review of the literature. Anesthesiology. Vol.113, No.2, (August 2010), pp. 482-95, ISSN 0003-3022 
[48] Hebert PC, Wells G, Blajchman MA, Marshall J, Martin C, Pagliarello G, Tweeddale M, Schweitzer I \& Yetisir E (1999). A multicenter, randomized, controlled clinical trial of transfusion requirements in critical care. Transfusion Requirements in Critical Care Investigators, Canadian Critical Care Trials Group. New England Journal of Medicine. Vol.340, No.6 (February 11, 1999), pp. 409-17, ISSN 0028-4793

[49] Hebert PC, McDonald BJ \& Tinmouth A (2004): Overview of transfusion practices in perioperative and critical care. Vox Sanguinis. Vol.87, No.Suppl 2, (July 2004), pp. 209-17, ISSN 1423-0410

[50] Wu WC, Rathore SS, Wang Y, Radford MJ \& Krumholz HM (2001). Blood transfusion in elderly patients with acute myocardial infarction. New England Journal of Medicine. Vol.345, No.17, (October 25, 2001), pp. 1230-6, ISSN 0028-4793

[51] Hebert PC, Wells G, Tweeddale M, Martin C, Marshall J, Pham B, Blajchman M, Schweitzer I \& Pagliarello G (1997). Does transfusion practice affect mortality in critically ill patients? Transfusion Requirements in Critical Care (TRICC) Investigators and the Canadian Critical Care Trials Group. American Journal of Respiratory and Critical Care Medicine. Vol.155, No.5 (May 1997), pp. 1618-23. ISSN 1535-4970

[52] Practice Guidelines for blood component therapy: A report by the American Society of Anesthesiologists Task Force on Blood Component Therapy. Anesthesiology. Vol.84, No.3, (March 1996), pp. 732-47, ISSN 0003-3022

[53] Marik PE \& Corwin HL (2008). Efficacy of red blood cell transfusion in the critically ill: a systematic review of the literature. Critical Care Medicine. Vol 36, No.9, (September 2008), pp. 2667-74, ISSN 0090-3493

[54] Swerdlow PS. Red cell exchange in sickle cell disease. Hematology. Vol.2006, pp. 48-53, ISSN 1520-4383

[55] Ho GT, Innes JA, Shand AG \& Satsangi J (2006). Bronchopulmonary manifestations of inflammatory bowel disease: a case report and literature review. The Journal of the Royal College of Physicians of Edinburgh. Vol.36, No.4, (November 2006), pp. 299-303, ISSN 2042-8189

[56] Tzanakis N, Samiou M, Bouros D, Mouzas J, Kouroumalis E \& Siafakas NM (1998). Small airways function in patients with inflammatory bowel disease. American Journal of Respiratory and Critical Care Medicine. Vol.157, No.2, (February 1998), pp. 382-6, ISSN: 1535-4970

[57] Adenis A, Colombel JF, Lecouffe P, Wallaert B, Hecquet B, Marchandise X \& Cortot A (1992). Increased pulmonary and intestinal permeability in Crohn's disease. Gut. Vol.33, No.5, (May 1992), pp. 678-82, ISSN 0017-5749

[58] Heatley RV, Thomas P, Prokipchuk EJ, Gauldie J, Sieniewicz DJ, Bienenstock J. Pulmonary function abnormalities in patients with inflammatory bowel disease. The Quarterly Journal of Medicine. Vol.51, No.203, (Summer 1982), pp. 241-50, ISSN 1460-2393

[59] King TE Jr (1989). Bronchiolitis obliterans. Lung. Vol.167, No.1, (December 1989), pp. 69-93, ISSN 1432-1750 
[60] Essadki O \& Grenier P (1999). Bronchiolitis: computed tomographic findings. Journal de Radiologie. Vol.80, No.1, (January 1999), pp. 17-24, ISSN 0221-0363

[61] Camus P \& Colby TV (2000). The lung in inflammatory bowel disease. European Respiratory Journal. Vol.15, No.1, (January 2000), pp. 5-10, ISSN 1399-3003.

[62] Foucher P, Biour M, Blayac JP Godard P, Sgro C, Kuhn M, Vergnon JM, Vervloet D, Pfitzenmeyer P, Ollagnier M, Mayaud C \& Camus P (1997). Drugs that may injure the respiratory system. European Respiratory Journal. Vol.10, No.2, (February 1997), pp. 265-79, ISSN 0903-1936

[63] Camus P, Piard F, Ashcroft T, Gal AA \& Colby TV (1993). The lung in inflammatory bowel disease. Medicine (Baltimore).Vol.72, No.3, (May 1993), pp. 151-83, ISSN 1536-5964.

[64] Searles G \& McKendry RJ (1987). Methotrexate pneumonitis in rheumatoid arthritis: potential risk factors. Four case reports and a review of the literature. Journal of Rheumatology. Vol.14, No.6, (December 1987), pp. 1164-71, ISSN 1499-2752

[65] Egan LJ \& Sandborn WJ (1996). Methotrexate for inflammatory bowel disease: pharmacology and preliminary results. Mayo Clinic Proceedings. Vol.71, No.1, (January 1996), pp. 69-80, ISSN 1942-5546

[66] Stein RB \& Hanauer SB (2000). Comparative tolerability of treatments for inflammatory bowel disease. Drug Safety. Vol.23, No.5, (November 2000), pp. 429-48, ISSN 01145916

[67] Warris A, Bjorneklett A \& Gaustad P (2001). Invasive pulmonary aspergillosis associated with infliximab therapy. New England Journal of Medicine. Vol.344, No.14, (April 5, 2001), pp. 1099-100, ISSN 0028-4793

[68] Ezri T, Kunichezky S, Eliraz A, Soroker D, Halperin D \& Schattner A (1994). Bronchiolitis obliterans-current concepts. The Quarterly Journal of Medicine. Vol.87, No.1 (January 1994), pp. 1-10, ISSN 1460-2393

[69] Epler GR, Colby TV, McLoud TC, Carrington CB \& Gaensler EA (1985). Bronchiolitis obliterans organizing pneumonia. New England Journal of Medicine. Vol. 312, No.3, (January 17, 1985), pp. 152-8, ISSN 0028-4793

[70] Weterman IT, Biemond I \& Peña AS (1990). Mortality and causes of death in Crohn's disease. Review of 50 years' experience in Leiden University Hospital. Gut, Vol.31, No.12, (December 1990), pp. 1387-90, ISSN 0017-5749

[71] Basturk T, Ozagari A, Ozturk T, Kusaslan R \& Unsal A (2009). Crohn's disease and secondary amyloidosis: early complication? A case report and review of the literature. Journal of Renal Care. Vol.35, No.3, (September 2009), pp. 147-50, ISSN 1755-6686

[72] Greenstein AJ, Sachar DB, Panday AK, Dikman SH, Meyers S, Heimann T, Gumaste V, Werther JL \& Janowitz HD. Amyloidosis and inflammatory bowel disease. A 50year experience with 25 patients. Medicine (Baltimore). Vol.71, No.5, (September 1992), pp. 261-70, ISSN 1536-5964

[73] Lovat LB, Madhoo S, Pepys MB \& Hawkins PN (1997). Long-term survival in systemic amyloid A amyloidosis complicating Crohn's Disease. Gastroenterology. Vol.112, No.4, (April 1997), pp. 1362-5, ISSN 0016-5085 
[74] Palma CL, Grünholz D \& Osorio G (2005). Clinical features of patients with the pathological diagnosis of amyloidosis. Revista Medica de Chile. Vol.133, No.6 (June 2005), pp. 655-61, ISSN 0717-6163

[75] Seijo Ríos S, Barreiro de Acosta M, Vieites Pérez-Quintela B, Iglesias Canle J, Forteza J \& Domínguez Muñoz JE (2008). Secondary amyloidosis in Crohn's disease. Revista Espanola de Enfermedades Digestivas. Vol.100, No.12, (December 2008), pp. 792-7, ISSN 1130-0108.

[76] Mayer EA \& Gebhart GF (1994). Basic and clinical aspect of visceral hyperalgesia. Gastroenrerology. Vol.107, No.1, (July 1994), pp. 271-93, ISSN 0016-5085

[77] Schreiber S, Raedler A, Stenson WF \& MacDermott RP (1992). The role of the mucosal immune system in inflammatory bowel disease. Gastroenterology Clinics of North America. Vol.21, No.2, (June 1992), pp. 451-502, ISSN 0889-8553

[78] Dray A (1995). Inflammatory mediators in pain. British Journal of Anaesthesia. Vol.75, No.2, (August 1995), pp. 125-31, ISSN 0007-0912

[79] Gebhart GF (1999). Peripheral contributions to visceral hyperalgesia. Canadian Journal of Gastroenterology. Vol.13, No.Suppl A, (March 1999), pp. 37A-41A. ISSN 0835-7900

[80] Weeke B \& Jarnum S (1971). Serum concentration of 19 serum proteins in Crohn's disease and ulcerative colitis. Gut. Vol.12, No.4, (April 1971), pp. 297-302, ISSN 0017-5749

[81] Schirbel A, Reichert A, Roll S, Baumgart DC, Büning C, Wittig B, Wiedenmann B, Dignass A \& Sturm A (2010). Impact of pain on health-related quality of life in patients with inflammatory bowel disease. World Journal of Gastroenterology. Vol.16, No.25, (July 7, 2010), pp. 3168-77, ISSN 1007-9327

[82] Ballantyne JC \& Mao J (2003). Opioid therapy for chronic pain. New England Journal of Medicine. Vol.349, No.20, (November 13, 2003), pp. 1943-53, ISSN 0028-4793

[83] Smith JP, Stock H, Bingaman S, Mauger D, Rogosnitzky M \& Zagon IS (2007). Lowdose naltrexone therapy improves active Crohn's disease. American Journal of Gastroenterology. Vol.102, No.4, (April 2007), pp. 820-8, ISSN 1572-0241

[84] Grover M, Herfarth H \& Drossman DA (2009). The functional-organic dichotomy: postinfectious irritable bowel syndrome and inflammatory bowel disease-irritable bowel syndrome. Clinical Gastroenterology and Hepatology. Vol.7, No.1, (January 2009), pp. 48-53, ISSN 1542-3565

[85] Gesink-van der Veer BJ, Burm AG, Vletter AA \& Bovill JG (1993). Influence of Crohn's disease on the pharmacokinetics and pharmacodynamics of alfentanil. British Journal of Anaesthesia. Vol.71, No.6, (December 1993), pp. 827-34, ISSN 00070912

[86] Guidat A, Fleyfel M, Vallet B, Desreumaux P, Levron JC, Gambiez L, Colombel JF \& Scherpereel P (2003). Inflammation increases sufentanil requirements during surgery for inflammatory bowel diseases. European Journal of Anaesthesiology. Vol.20, No.12, (December 2003), pp. 957-62, ISSN 0265-0215

[87] Verne GN, Robinson ME \& Price DD (2001). Hypersensitivity to visceral and cutaneous pain in the irritable bowel syndrome. Pain. Vol.93, No.1, (July 2001), pp.7-14, ISSN 0304-3959 
[88] Fleyfel M, Dusson C, Ousmane ML, Guidat A, Colombel JF, Gambiez L \& Vallet B (2008). Inflammation affects sufentanil consumption in ulcerative colitis. European Journal of Anaesthesiology. Vol.25, No.3, (March 2008), pp. 188-92. ISSN 0265-0215 


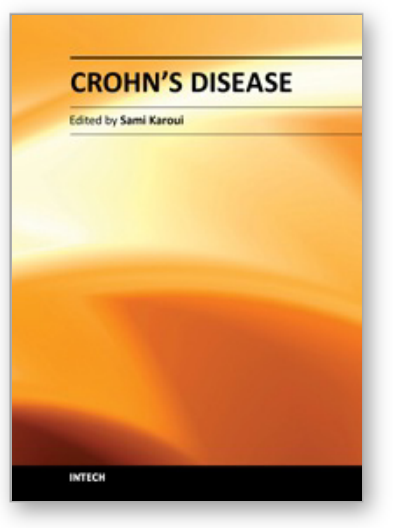

\author{
Crohn's Disease \\ Edited by Dr. Sami Karoui
}

ISBN 978-953-307-811-3

Hard cover, 210 pages

Publisher InTech

Published online 13, January, 2012

Published in print edition January, 2012

In this book, several important points regarding Crohn's disease are discussed. In the first section, we focus on etiopathogeny of Crohn's disease and the recent advances in our overall understanding of the disease specifically, the role of the gut epithelium, alterations of the epithelial crypts, and the roles of the different cytokines in the pathophysiology of Crohn's disease. In the second section, a diagnosis of Crohn's disease is discussed. Another particular area of focus is in the diagnosis of intestinal tuberculosis, and the role of mycobacterium avium in Crohn's disease. In the third and final section, the management of Crohn's disease is discussed, with a focus on recent evidence-based medicine recommendations.

\title{
How to reference
}

In order to correctly reference this scholarly work, feel free to copy and paste the following:

Beyazit Zencirci (2012). Crohn's Disease: From an Anesthetist's Perspective, Crohn's Disease, Dr. Sami Karoui (Ed.), ISBN: 978-953-307-811-3, InTech, Available from: http://www.intechopen.com/books/crohn-sdisease/crohn-s-disease-from-an-anesthetist-s-perspective

\section{INTECH}

open science | open minds

\section{InTech Europe}

University Campus STeP Ri

Slavka Krautzeka 83/A

51000 Rijeka, Croatia

Phone: +385 (51) 770447

Fax: +385 (51) 686166

www.intechopen.com

\section{InTech China}

Unit 405, Office Block, Hotel Equatorial Shanghai

No.65, Yan An Road (West), Shanghai, 200040, China

中国上海市延安西路65号上海国际贵都大饭店办公楼 405 单元

Phone: +86-21-62489820

Fax: +86-21-62489821 
(C) 2012 The Author(s). Licensee IntechOpen. This is an open access article distributed under the terms of the Creative Commons Attribution 3.0 License, which permits unrestricted use, distribution, and reproduction in any medium, provided the original work is properly cited. 